He, Kai. 2019. "Contested Multilateralism 2.0 and Regional Order Transition: Causes and Implications," The Pacific Review 32 (2): 210-220.

\title{
Contested Multilateralism 2.0 and Regional Order Transition: Causes and
}

\section{Implications}

\begin{abstract}
This article proposes a new concept of 'contested multilateralism 2.0' to describe the puzzling institutional building efforts by non-ASEAN members after the 2008 global financial crisis (GFC) in the Asia-Pacific. It suggests that different to 'multilateralism 1.0 ' of the $1990 \mathrm{~s}$, which was mainly led by ASEAN, this wave of multilateralism has been initiated by other powers, such as the United States, China, Japan, Australia, and South Korea, either by forming new institutions or by reinvigorating existing ones. This article advances an institutional balancing argument. It suggests that 'contested multilateralism 2.0' is a result of institutional balancing among major states under the conditions of high strategic uncertainty and high economic interdependence after the GFC. One unintended consequence may be that it could well lead to a more peaceful transformation of the regional order in the Asia-Pacific if regional security hotspots, such as the Korean crisis and the South China Sea dispute, can be managed appropriately.
\end{abstract}

Keywords: Multilateralism 2.0; Institutional Balancing; Regional Order Transformation; TPP; NAPCI; EAC; APC; OBOR; AIIB

\section{$\underline{\text { Author Bio: }}$}

Kai He is Professor of International Relations, Griffith Asia Institute and Center for Governance and Public Policy, Griffith University, Australia and visiting Chair Professor of International Relations at the Zhou Enlai School of Government, Nankai University, China.

\section{Acknowledgement:}

The author would like to thank the following scholars for their suggestions and advice on this project: Amitav Acharya, Victor Cha, Michael Green, Tsutomu Kikuchi, T.J. Pempel, Yoshihide Soeya, William Tow, Yoshinobu Yamamoto, and Stephen Walker as well as anonymous reviewer and the Editors of the Pacific Review. In particular, the author thanks Hiro Katsumata and Jun Honna for their help in organizing two seminars in Japan in April 2017. The paper was also presented at a conference funded by the Korea Foundation entitled "Contested Multilateralism 2.0 and Asia Pacific Security" in Brisbane in May 2017. The author is grateful for all the comments and suggestions from participants at the above seminars and conference. All errors and omissions are the author's own. 


\section{Contested Multilateralism 2.0 and Regional Order Transition: Causes and Implications}

The 2008 global financial crisis (GFC) introduced 'contested multilateralism 2.0' into the Asia-Pacific. Different to 'multilateralism 1.0' of the 1990s, which was mainly led by the Association of Southeast Asian Nations (ASEAN), this second wave of multilateralism was initiated by non-ASEAN members either by inaugurating new institutions or by reinvigorating existing establishments in the region. For example, Australian Prime Minister Kevin Rudd's 2009 proposal for an Asia Pacific Community (APC), which eventually morphed into the East Asia Summit (EAS), is illustrative, as was Japanese Prime Minister Yukio Hatoyama's advocacy for the building of an East Asian community (EAC) in the same year. In 2013, South Korean President Park Geunhye proposed the Northeast Asia Peace and Cooperation Initiative (NAPCI) to strengthen security cooperation in that sub-region. Chinese President Xi Jinping simultaneously advocated the building of a 'community of common destiny' in Asia in 2013, along with massive Chinese investments and financial initiatives, such as the 'One Belt, One Road' initiative. In December 2015, the Chinese-led Asian Infrastructure Investment Bank (AIIB) was successfully established with 57 prospective founding members despite US opposition.

As part of its 'pivot' or 'rebalancing' strategy toward Asia, the United States under the Barack Obama administration also actively engaged in this wave of 'multilateralism 2.0' through formally joining the EAS in 2011. In addition, Obama proactively promoted the Trans-Pacific Partnership (TPP) - a multilateral trading bloc that excluded China, with the twelve TPP countries finally reaching an agreement in 
October 2015. The rise of Donald Trump's presidency in 2017 has seemingly killed the TPP in its infancy, but his determination to secure 'better trade deals' for the United States represents an obvious US competitive orientation and signals a continued US role to contest Chinese leadership in the Asia-Pacific through a variety of existing regional instrumentalities and institutions.

The emergence of 'multilateralism 2.0' following the GFC in the Asia-Pacific is assessed in this article, with the aim of addressing two specific questions: why did major powers engage in this wave of 'multilateralism 2.0' in the Asia-Pacific? What are the implications of contested multilateralism for the evolving regional order? I suggest that two systemic variables - the higher strategic uncertainties in the region and deepening economic interdependence - prompted various Asia-Pacific powers to pursue institutional balancing to compete for advantage during what is clearly a time of order transition in the region.

Institutional balancing is a new type of balance of power strategy through which states can use multilateral institutions instead of traditional military means to compete for power and influence in world politics (He 2008; 2009). There are three types of institutional balancing. Inclusive institutional balancing means to include a target state in an institution and relies on the rules and norms of institutions to constrain the target state's behaviour. Exclusive institutional balancing refers to a strategy to exclude a target state from an institution and relies on the cohesion and cooperation inside the institution to exert pressure towards, or to neutralise threats from, the target state. Interinstitutional balancing is a means through which states can promote a new institution to reduce or dilute influences of existing institutions (He 2008; 2009). It is an extended form of both inclusive and exclusive institutional balancing. The target of inter- 
institutional balancing is not a state per se, but another institution that might or might not include the target state (Lee 2016).

This article argues that non-ASEAN members conducted various institutional balancing strategies in the 'multilateralism 2.0' era after the GFC, suggesting that overlapping multilateral institutions could well become a 'new normal' in the AsiaPacific as a result of intensified institutional balancing among major powers. One unintended consequence of this process is that it may lead to a more peaceful transformation toward a new Asia-Pacific economic and politico-security order.

\section{What is contested multilateralism 2.0?}

Asian multilateralism is not new in world politics. Since the end of the Cold War, various multilateral institutions have proliferated in the Asia-Pacific, marking 'multilateralism 1.0' in the region. A remarkable feature of 'multilateralism 1.0' was that it centred on ASEAN. The establishment of the ASEAN Regional Forum (ARF) in 1994, which has now expanded to 27 members, was the apex of this process. The ARF is the only security forum and dialogue mechanism that includes all major powers in the world (the European Union also participates in the annual ARF meeting as an institutional member). The EAS is another example of multilateralism 1.0. This grouping is an extended version of ASEAN Plus Three (APT), also driven by ASEAN. The United States and Russia formally joined the EAS in 2011. Although this ASEAN- 
centred multilateralism is widely criticised for its inefficiency or as talk-shops without teeth, ASEAN firmly remained in the 'driver's seat' for more than two decades. ${ }^{1}$

The second wave of multilateralism in the Asia-Pacific was triggered by the GFC. It involves the reinvigoration of existing institutions and the initiation of new establishments in the region. It has three distinctive features. First, it is driven by major powers - the United States, China, Australia, Japan, and South Korea - not ASEAN. Second, it is comprehensive in addressing both traditional and non-traditional security and economic challenges with a geopolitical emphasis on East Asia in particular and the Asia-Pacific in general, instead of being mainly Southeast Asian-centric. Third, it coexists, competes, and interacts with 'multilateralism 1.0' and with other forms of security organisations, such as US-led bilateralism, as well as nascent minilateral arrangements in shaping the Asia-Pacific's future regional order.

Some scholars have proposed similar concepts to 'contested multilateralism' or 'multilateralism 2.0'. Julia Morse and Robert Keohane (2014: 385) define 'contested multilateralism' as a situation that 'results from the pursuit of strategies by states, multilateral organizations, and non-state actors to use multilateral institutions, existing or newly created, to challenge the rules, practices, or missions of existing multilateral institutions.' In a similar vein, Luk Van Langenhove (2010: 263) argues that a transformation of multilateralism mode 1.0 to mode 2.0 is taking place, the main characteristics being: '(1) the diversification of multilateral organisations; (2) the growing importance of nonstate actors such as substate regions and supranational

\footnotetext{
${ }^{1}$ For positive as well as negative evaluations on ASEAN and ASEAN-centered multilateralism, see Smith (2004); Severino (2007); Leifer (1999); Jones and Smith (2007); Emmerson (2007); Ravenhill (2009).
} 
regional organisations; (3) the increased interlinkages between policy domains; and (4) the growing space for citizen involvement.'

However, the idea of 'contested multilateralism 2.0' in the Asia-Pacific introduced here differs from Morse and Keohane (2014) and Langenhove (2010) in two different and important ways. First, the nation-state remains the major actor of 'contested multilateralism 2.0', superseding institutional, sub-state and non-state actors. Second, the 'contestation' aspect of the multilateralism 2.0 variant under review here refers to both intra-institutional and inter-institutional competition among state actors through multilateral means. The reason for coining 'multilateralism 2.0' in this context is to differentiate this second wave of multilateralism as it is now unfolding in Asia from the previous 'multilateralism 1.0' led by ASEAN soon after the Cold War. It does not imply that the changing nature of world politics is based on the primacy shifting from nation-states to non-state actors as the other two conceptualisations cited above suggest (although it is clear that the roles of non-state actors are commanding increased importance in international relations).

\section{Why is there contested multilateralism 2.0?}

Different arguments have been offered to explain why 'contested multilateralism 2.0' has become more prominent. Neorealists and some others embracing a broader realist outlook suggest that institutions are just an epiphenomenon of power politics among great powers (Mearsheimer 1994). Therefore, so-called contested multilateralism is just another name for power politics among states. For example, Marc Lanteigne (2005) suggests that China used multilateral institutions such as the ARF as a diplomatic tool to pursue its great-power status after the Cold War. 
At a time when observers are increasingly engrossed with China's (invariable) rise, America's (possible) decline and an increasingly multipolar international security environment, Bates Gill and Michael Green (2008: 3) point out that 'Asia's new multilateralism is still at a stage where it is best understood as an extension and intersection of national power and purpose rather than as an objective force in itself.' For example, China actively advocated the 'New Asian Security' concept - the 'Asiafor-Asians' idea - at the Conference on Interaction and Confidence-Building Measures in Asia (CICA) in 2014. This initiative was seen by outside observers as a countervailing effort against the United States, which started to 'pivot to Asia' in 2011 (Anderlini 2014).

Conversely, liberalism, especially neoliberalism, argues that the impact of institutions in contemporary world politics is significant because they reduce transaction costs and foster cooperation among states (Keohane and Martin 1995). This outlook likewise privileges the nation-state as the primary agent of concern, although in a markedly different way than its realist/neorealist counterpart. Liberals/neoliberals insist that multilateralism 2.0 is rooted in the functional imperative for states facing emerging regional security challenges in Asia to embrace targeted modes of cooperation which, if absent, could only lead to crisis escalation or worse. For example, Richard Stubbs (2002) praises the functional success of APT as a new regional institution in promoting economic cooperation between Southeast Asia and Northeast Asia after the 1997 Asian economic crisis. Similarly, the establishment of the AIIB led by China in 2015 is also intended to address the insufficient investments in infrastructure in Asian developing countries. 
Last, but not least, a constructivist school of thought sees institutions and multilateralism as reflecting certain ideas and the norms emanating from them as underwriting world politics (Wendt 1995, 1999). In the case of the Asia-Pacific region, the ASEAN-dominated 'multilateralism 1.0' in the 1990s was built on a shared 'wefeeling' among ASEAN members about how their collective identity was nurtured relative to regional order-building (Acharya 2001). For the 'contested multilateralism 2.0' phenomenon, constructivists suggest that it is a clash of different visions or ideas among major powers on how regional order-building should evolve (He 2016).

For example, former Japanese Prime Minister Hatoyama proposed an EAC, which is based on a shared culture and civilisation among Asian countries. A particularly unique aspect of Asians' approaches to order-building is their emphasis on a distinct regional culture or civilisation. As Hatoyama (2010) states, 'one characteristic of Asians is that we do not perceive ourselves and others or humans and the environment in a western dualistic manner, but rather attach importance to the sameness between the two ... This will surely also serve as a launching point for a "cultural community".' Hatoyama's civilisation-based EAC proposal is quite different from Rudd's more 'Western-centric' APC suggestion, which embodied a much broader geographical scope, including non-Asian countries (Australia and the United States) as well as normative and legalistic principles (Frost 2009; Rudd 2008). Arguably, these different visions and ideas of regional order led to the emergence of 'contested multilateral 2.0' in the Asia-Pacific.

Although these three contending approaches reveal some elements of truth, they fail to explain the timing, complicity among actors, and dynamics of 'contested multilateralism 2.0' after the GFC. Realists are correct to suggest that multilateralism 
and multilateral institutions are an extension of power politics among major powers. However, why and how did major powers instigate this new wave of multilateralism after the 2008 GFC? Power transition theorists would explain this development as a result of intensified competition between the United States and China (see, for example, Danilovic and Clare 2007; Allison 2017). However, they face difficulties in accounting for the active institutional involvement of other powers, such as Australia, Japan, and South Korea.

It is also true, as neoliberals have suggested, that some new institutions forged during the multilateralism 2.0 timeframe fit the functional needs of the region. Still, the EAC, the APC, and China's community of common destiny are examples of competitive approaches to linking preferred economic models to more comprehensive strategies for strengthening major powers' positionality. Accordingly, these initiatives seem to go beyond the mere functional boundary emphasised by neoliberals. For constructivists, ideas constitute the basic fundamental motivating agent behaviour in international relations. However, purely ideational competition among states cannot really account for all the behavioural dynamics of states as it has transpired under multilateralism 2.0 in the Asia-Pacific. Why did the United States continue to support such existing institutions as the EAS and the TPP while other major powers hedged against possible US retrenchment from the region by proposing various new institutions? Moreover, constructivists' ideational arguments cannot explain why these other powers proposed these multilateral institutions soon after the financial crisis, not significantly earlier or much later. The timing problem cannot be addressed by the contingent ideas and visions of political leaders alone. 


\section{Potential order transition and institutional balancing}

As mentioned earlier, an 'institutional balancing' argument sheds additional light on the emergence of 'contested multilateralism 2.0'. Focusing on two systemic variables - the high level of uncertainties and high economic interdependence - is particularly useful for developing a greater understanding of the convergence of multilateral behaviour among different states.

The 2008 GFC began in the United States and quickly spread to the rest of the world. The daunting and widespread impact of the crisis on the world economy revealed two new trends in world politics: the rapid decline of the US-led liberal order since the Second World War, and the deepening economic interdependence among states. As G. John Ikenberry (2012: 4) points out, 'the 2008 financial crisis and subsequent world economic downturn - the most severe since the Great Depression - was an especially stark demonstration of the pressures on the American-led liberal system.' Compared to the relative decline of US power, the 'rise of the rest' became a new feature of world politics (Zakaria 2008). In the Asia-Pacific, China's sustained economic growth during the GFC triggered both a power transition between the United States and China as well as a regional order transformation from the old US-led order to an uncertain regional flux.

The GFC's widespread damage also reflected a core trend of globalisation - a deepening economic interdependence among states. In the Asia-Pacific this interdependence featured increasing intra-regional trade and investment. As the Asian Development Bank (2016: x, 18) has since observed, 'Asian economies traded with regional partners well beyond what geographical, cultural, or economic proximity can explain; with $57.1 \%$ of total trade intraregional.' Although it is still lower than the 
European Union (63 per cent), it is much higher than the intra-regional trade in North America (25 per cent). Moreover, the intra-regional foreign direct investment to and from Asia and the Pacific has increased over time and reached 52.5 per cent of total foreign direct investment inflows in 2015 (Asian Development Bank 2016: xi).

The GFC, therefore, marked the beginning of an Asia-Pacific regional order transition from the previous US-led hegemonic system and liberal order to a more uncertain condition of fluctuating multipolarity. This growing level of strategic uncertainty in the region, combined with deepening economic interdependence among Asia-Pacific states, encouraged those countries' policy elites to deem institutions as venues for competing for greater power and influence. This epitomised traditional balance of power behaviour among states under anarchy. The potential order transition after the GFC, moreover, intensified the 'balancing' activities among states through institutions. Major powers and other states in the region perceived both risks and opportunities accompanying the power transition process, and the emergence of contested multilateralism 2.0 was an inevitable by-product of institutional balancing among these countries.

Institutional balancing theory suggests that high economic interdependence encourages states to employ institutions to realise relative gains (as realists would predict) such as power and influence (He 2009). Recalling the previous definition of institutional balancing offered earlier, one can discern the ARF as an example of inclusive institutional balancing of ASEAN members toward China through which China's behaviour in the South China Sea in the 1990s was constrained by the ARF's cooperative security rules and norms (Foot 1998; He 2008; Katsumata 2009). In 'multilateralism 2.0', China's AIIB and One Belt, One Road initiative exemplify 
inclusive institutional balancing adopted by China to increase its regional power and influence through forming new rules and norms for financial and economic governance in the Asia-Pacific.

An example of exclusive institutional balancing is the APT in the ‘multilateralism 1.0' era. ASEAN and three major powers - China, Japan, and South Korea - used this grouping to promote economic cooperation among Asian countries after the 1997 Asian economic crisis in order to express resentment toward, as well as countervail pressures from, the United States and its control of the International Monetary Fund (Stubbs 2002; Beeson 2003). Under the Obama administration, the TPP was an exclusive institutional balancing strategy of the United States against China because the high trading and investment standards intentionally excluded China from the TPP. The success of the TPP would inevitably reduce China's power and influence in the region. The Obama administration embraced inter-institutional balancing by actively promoting the TPP, which technically excluded China due to the high entry standards of the TPP. In order to counter the TPP, China supported the establishment of the Regional Economic Cooperation Partnership (RECP), a rival trading bloc that is built on the APT framework. Therefore, the RECP can be seen as an inter-institutional balancing effort of China against the US-led TPP.

After the 2008 GFC, all major Asia-Pacific powers devoted more attention to how to shape the new regional order. It is worth noting that the 2008 GFC is just a direct trigger of the "perceived order transition," which accounts for the timing but not the emergence of this new wave of multilateralism in the Asia Pacific. The fundamental driver of the order transition is the rapid rise of China and the relative decline of the United States in the post-Cold War era. The 2008 GFC, at the most, seems to further 
vindicate this inevitable trend of power transition between the United States and China as well as a potential order transition in the Asia Pacific. The existing ASEAN-based multilateralism, supported by the ARF, the APT, and the EAS, was viewed as insufficient to address strategic uncertainties that would accompany order transition. Institutional balancing - relying on multilateral institutions to maximise power and influence - surfaced as a useful diplomatic tool for states to pursue a more favourable positionality. Therefore, a new wave of multilateralism appeared in the Asia-Pacific, in which major powers started to compete for institutional leadership through either initiating new institutions or reviving existing ones.

For example, South Korea proposed the establishment of the NAPCI in 2013 under the Park administration to 'build trust and foster a spirit of cooperation in the region by accumulating a habit of cooperation among regional partners' (Korean Ministry of Foreign Affairs 2013: 13). As Lee Sang-Hyun (2014) points out, '[a] vacuum in leadership has perpetuated the absence of coordination towards the construction of a regional multilateral security framework' in Northeast Asia. And 'South Korea may be better poised to promote NAPCI, free from great power rivalry and competition, particularly among the United States, China, and Japan.' It is clear that the NAPCI was seen as an opportunity for South Korea to play a critical or even a leadership role in building a new regional order in the future. The potential target of the NAPCI is the ASEAN-driven ARF.

Both Hatoyama's EAC initiative and Rudd's APC proposal exemplified the use of inter-institutional balancing strategy to at least complement if not outright supplant ASEAN's 'multilateralism 1.0'. They were both geared to maximise the potential influence of Japan and Australia respectively in any future Asia-Pacific regional order. 
Unfortunately for them, both the EAC and APC proposals became mere 'thought bubbles' due to their domestic political situations and naïveté about regional and alliance sensitivities overwhelming their visionary geopolitics. Hatoyama's adoption of 'muddle through' tactics for finessing his own political party's management of Japan's alliance with the United States, and Rudd's inability to control rival factions in the Australian Labor Party and ASEAN resentment over his failure to consult about his APC proposal before he publicly revealed it, simply eclipsed their foreign policy innovations (see Clausen 2012; Lee and Milner 2014). However, future political leaders in Japan and Australia may be more successful in implementing inter-institutional balancing with new ideas and initiatives if they intend to play a more active role in shaping the regional order toward their preferences and interests.

\section{Conclusion: Peaceful order transition as an unintended consequence?}

Various scholars have heatedly debated the implications of Asian multilateralism for regional order since the end of the Cold War (see, for example, Simon 1995; Leifer 1999; Acharya 2004; Jones and Smith 2007). Some assert that ASEAN-driven multilateralism in the 1990s was making process not progress; others suggest that the mere process of ASEAN multilateralism signifies the success of ASEAN in mitigating regional rivalries and tensions. The rise of 'contested multilateralism 2.0' after the GFC has encouraged major powers to further engage in a new wave of institutional building and competition in the Asia-Pacific. Although the overlap and redundancy of multilateral institutions seems inevitable, this 'contested multilateralism 2.0' phenomenon has at least three strategic implications for the regional order in the AsiaPacific. 
First, contested multilateralism 2.0 will reflect the power transformation in the regional system. The decline of US hegemony and the rise of the rest, especially China, will transfer the regional power configuration from unipolarity to either bi-multipolarity or multipolarity. In a bi-multipolar system the United States and China will dominate the institutional competition during the multilateralism 2.0 era, in which other states will have to pick sides between US-dominated institutions and China-centred ones. In a multipolar system, middle powers or second-tier powers, such as Australia, Japan, and South Korea, might rise up to become independent forces if they can seize the opportunity to build multilateral institutions and strengthen their voices in Asian affairs. Second, the new and revived institutions in the 'multilateralism 2.0' era will compete with and complement the ASEAN-driven multilateral institutions in mitigating regional tensions. The rise of multilateralism 2.0 will, however, unavoidably threaten the relevance of ASEAN-driven institutions. For example, if the community of common destiny proposed by China succeeds, the role of the EAS and the APT in regional affairs will be eroded. As T. J. Pempel (2010) argues, institutional Darwinism will determine the rise and fall of multilateral institutions in the Asia-Pacific. However, it is not an automatic process because the sunk costs of abandoning an existing institution and the opportunity costs of establishing a new one are relatively high for states in world politics. We are more likely to see that 'multilateralism 2.0 ' will co-exist with 'multilateralism 1.0 ' in the foreseeable future.

Moreover, the future of multilateralism 2.0 will face more challenges from traditional power politics. The nuclear and missile crises on the Korean Peninsula and the territorial and maritime disputes in the East and South China Seas, as well as the border dispute between China and India, are all security hotpots that might encourage 
states to pursue unilateralism or traditional balance of power mechanisms for short-term gains in regional security. The relevance of multilateralism 2.0 , together with the ASEAN-driven multilateralism 1.0, will be seriously questioned and also tested during military and diplomatic crises in the region. Given the complicated nature of these regional security issues, no country seems able to address these challenges alone. Multilateralism is by no means a panacea either. How to effectively integrate traditional military means and multilateralism in coping with security dynamics becomes an imperative task for policymakers in the region.

If managed appropriately, these new multilateral institutions can complement the existing ones in mitigating regional rivalries and tensions among states. For example, if South Korea's NAPCI proposal was successfully implemented, it would have complemented the role of the ARF in enhancing mutual trust and cooperation among Northeast Asian states. Unfortunately, the future of the NAPCI was officially over along with the downfall of President Park in South Korea. Will South Korea's new President Moon initiate a new multilateral framework to cope with the deteriorating situation on the Korean Peninsula? Will the United States and China resume the Six Party Talks or other similar security institutions to rein in North Korea? Or will Trump deal with Kim jong-un alone? These questions are hard to answer right now. Things might get worse before they get better. Nevertheless, multilateralism remains a useful diplomatic tool for states to maintain regional security in the long run. More importantly, major powers, such as China and the United States, will need to offer leadership and public goods in the designated institutions if they further engage the multilateralism 2.0 era. The Sino-American competition for providing public goods will exert positive externalities on the regional order. 
Last, the emergence of multilateralism 2.0 could potentially facilitate a peaceful order transition in the region in the long run. Unlike power transition theory, which suggests that war or conflict is inevitable among great powers during a power transition, it has been argued here that the order transition based on institutional balancing might be more peaceful than is currently widely perceived. Although the purpose of institutional balancing is to compete for dominance and power in multilateral institutions as well as in the new regional order, the means of institutional balancing is different from traditional hard power strategies, such as alliance formation and arms build-ups. Rule-making and agenda-setting are the major features of institutional balancing. Although exclusive institutional balancing might be more hostile and antagonistic than inclusive institutional balancing, the overlapping nature of the 'contested multilateralism 2.0' regional order to a certain extent is, under certain conditions and circumstances, capable of mitigating potential tensions and rivalries among states (Yeo 2016).

In this context, there may be grounds for optimism. Although China was excluded from the TPP under the Obama administration, both China and the United States are members of the Asia-Pacific Economic Cooperation grouping and the proposed Asia-Pacific free trade agreement. In the same vein, although the United States is not a member of the CICA organisation promoted and revived by China in 2014, both the United States and China are members of the ARF. Although the overlapping institutions in the era of multilateralism 2.0 may presently seem redundant and inefficient in solving regional disputes, it could be equally surmised that this overlapping multilateralism is inevitable due to intensified institutional balancing among major Asia-Pacific powers. An unintended consequence of this institutional 
overlap could therefore be a peaceful order transformation by default. This outcome, of course, would be more likely if major powers can find a new equilibrium among power, interests, and norms in whatever new regional architecture that does materialise, and if security hotspots in the region are managed appropriately.

\section{References}

Acharya, Amitav (2001) Constructing a Security Community in Southeast Asia: ASEAN and the Problem of Regional Order, London and New York: Routledge.

Acharya, Amitav (2004) 'How ideas spread: Whose norms matter? Norm localization and institutional change in Asian regionalism', International Organization 58(2): 239-75.

Allison, Graham T. (2017) Destined for War: Can America and China Escape Thucydides 's Trap? Melbourne and London: Scribe.

Anderlini, Jamil (2014) 'China reinvigorates regional clubs to counter US power', Financial Times, 20 May.

Asian Development Bank (2016) Asian Economic Integration Report 2016: What Drives Foreign Direct Investment in Asia and the Pacific?, Manila: Asian Development Bank.

Beeson, Mark (2003) 'ASEAN plus three and the rise of reactionary regionalism', Contemporary Southeast Asia 25(2): 251-68.

Clausen, Daniel (2012) 'Examining Japanese defense policy and politics through failures of leadership: The case of Prime Minister Hatoyama Yukio’, Asian Politics \& Policy 4(4): 507-25. 
Danilovic, Vesna and Clare, Joe (2007) 'Global power transitions and regional interests', International Interactions 33(3): 289-304.

Emmerson, Donald K. (2007) 'Challenging ASEAN: A “Topological” View', Contemporary Southeast Asia 29(3): 424-46.

Foot, Rosemary (1998) 'China in the ASEAN Regional Forum: Organizational processes and domestic modes of thought', Asian Survey 38(5): 425-40.

Frost, Frank (2009) ‘Australia's proposal for an “Asia Pacific Community”: Issues and prospects', Parliamentary Library Research Paper, Canberra: Department of Parliamentary Services.

Gill, Bates and Green Michael J. (2008) 'Unbundling Asia’s new multilateralism', in Michael J. Green and Bates Gill (eds), Asia's New Multilateralism: Cooperation, Competition, and the Search for Community, New York: Columbia University Press, pp. 1-29.

Hatoyama, Yukio (2010) 'Speech by H. E. Dr Yukio Hatoyama Prime Minister of Japan on the Occasion of the Sixteenth International Conference on the Future of Asia Hosted by the Nihon Keizai Shimbun', 20 May.

He, Baogang (2016) Contested Ideas of Regionalism in Asia, London and New York: Routledge, 2016.

He, Kai (2008) 'Institutional balancing and international relations theory: Economic interdependence and balance of power strategies in Southeast Asia', European Journal of International Relations 14(3): 489-518.

He, Kai (2009) Institutional Balancing in the Asia Pacific: Economic Interdependence and China's Rise, London and New York: Routledge. 
Ikenberry, G. John (2012) Liberal Leviathan: The Origins, Crisis, and Transformation of the American World Order, Princeton, NJ: Princeton University Press.

Jones, David Martin and Smith, Michael L. R. (2007) 'Making process, not progress: ASEAN and the evolving East Asian regional order', International Security 32(1): $148-84$.

Katsumata, Hiro (2009) ASEAN's Cooperative Security Enterprise: Norms and Interests in the ASEAN Regional Forum, New York: Palgrave Macmillan.

Keohane, Robert O. and Martin, Lisa L. (1995) 'The promise of institutionalist theory', International Security 20(1): 39-51.

Korean Ministry of Foreign Affairs (2013) 'Northeast Asia Peace and Cooperation Initiative', Seoul: Korean Ministry of Foreign Affairs.

Langenhove, Luk Van (2010) 'The transformation of multilateralism mode 1.0 to mode 2.0', Global Policy 1(3): 263-70.

Lanteigne, Marc (2005) China and International Institutions: Alternative Paths to Global Power, London: Routledge.

Lee, Seungjoo (2016) 'Institutional balancing and the politics of mega-FTAs in East Asia’, Asian Survey 56(6): 1055-76.

Lee, Sang-Hyun (2014) 'The Northeast Asia Peace and Cooperation Initiative (NAPCI): A vision toward sustainable peace and cooperation in Northeast Asia', The ASAN Forum, 13 December.

Lee, Sheryn and Milner, Anthony (2014) 'Practical vs. identity regionalism: Australia's APC initiative, a case study', Contemporary Politics 20(2): 209-28.

Leifer, Michael (1999) 'The ASEAN peace process: A category mistake', Pacific Review 12(1): 25-39. 
Mearsheimer, John J. (1994) 'The false promise of international institutions', International Security 19(3): 5-49.

Morse, Julia C. and Keohane, Robert O. (2014) ‘Contested multilateralism', Review of International Organizations 9(4): 385-412.

Pempel, T. J. (2010) 'Soft balancing, hedging, and institutional Darwinism: The economic-security nexus and East Asian regionalism', Journal of East Asian Studies 10(2): 209-38.

Ravenhill, John (2009) 'East Asian regionalism: Much ado about nothing?' Review of International Studies 35(S1): 215-35.

Rudd, Kevin (2008) 'Building on ASEAN's success: Towards an Asia-Pacific community', Singapore: Institute of Southeast Asian Studies.

Severino, Rodolfo C. (2007) 'ASEAN beyond forty: Towards political and economic integration', Contemporary Southeast Asia 29(3): 406-23.

Simon, Sheldon W. (1995) 'Realism and neoliberalism: International relations theory and Southeast Asian security', Pacific Review 8(1): 5-24.

Smith, Anthony L. (2004) 'ASEAN's ninth summit: Solidifying regional cohesion, advancing external linkages', Contemporary Southeast Asia 26(3): 416-33.

Stubbs, Richard (2002) 'ASEAN plus three: Emerging East Asian regionalism?’ Asian Survey 42(3): 440-55.

Wendt, Alexander (1995) 'Constructing international politics', International Security 20(1): 71-81.

Wendt, Alexander (1999) Social Theory of International Politics, Cambridge: Cambridge University Press. 
Yeo, Andrew I. (2016) 'Overlapping regionalism in East Asia: Determinants and potential effects', International Relations of the Asia-Pacific https://doi/10.1093/irap/lcw015, 1-31.

Zakaria, Fareed (2008) 'The future of American power: How America can survive the rise of the rest', Foreign Affairs 87(3): 18-43. 